
Also by Joseph Wittreich

The Romantics on Milton

Angel of Apocalypse

Visionary Poetics

Image of That Horror

Interpreting "Samson Agonistes" 


\section{Joseph Wittreich}

\section{FEMINIST MILTON}

Cornell University Press

ITHACA AND L ONDON 


\section{Copyright (C) 1987 by Cornell University}

All rights reserved. Except for brief quotations in a review, this book, or parts thereof, must not be reproduced in any form without permission in writing from the publisher. For information, address Cornell University Press, I 24 Roberts Place, Ithaca, New York I4850.

First published 1987 by Cornell University Press.

International Standard Book Number 0-8014-2069-5

Library of Congress Catalog Card Number 87-47607

Printed in the United States of America

Librarians: Library of Congress cataloging information appears on the last page of the book.

The paper in this book is acid-free and meets the guidelines for permanence and durability of the Committee on Production Guidelines for Book Longevity of the Council on Library Resources. 
go little book

\section{to Esther Harbage Richardson, Charlotte Calvin Voorhis, Joel Conarroe, and James Thorpe}

.. there is love in their faces always, wisdom in their eyes, and in their steps, dignity and grace... 
Our Wives read Milton.

-Alexander Pope (1737)

Milton disdained me not.

-Mrs. Pedia (1763)

My landlady, who is only a taylor's widow, reads her Milton; and tells me, that her late husband first fell in love with her, on this very account; because she read Milton with such proper emphasis.

-C. P. Moritz (1782) 